\title{
Tuning growth versus defence-belowground interactions and plant resource allocation
}

\author{
Michael Schloter • Reiner Matyssek
}

Received: 19 April 2009/Accepted: 8 June 2009/Published online: 12 September 2009

(C) Springer Science + Business Media B.V. 2009

As substrate and energy resources in plants are limited, there is a need for plants for a well balanced trade-off, which allows growth but does not exclude defense mechanisms. This is addressed by the "Growth-Differentiation-Balance Theory" (GDB; Loomis 1953; Lorio 1988) as accentuated by Herms and Mattson (1992) and adapted by Matyssek et al. (2002, 2005). However, this theory suffers from substantial deficits in the understanding of mechanisms that underlie the balance between resource sequestration (as mediated through the plant's competitiveness related to growth) and retention (as a result of defence). Therefore since 1998 an integrative research center, entitled "Growth and Parasite Defense-Competition for Resources in Economic Plants from Agronomy and Forestry" (Sonderforschungsbereich 607, SFB 607, funded by

Responsible Editor: Hans Lambers.

M. Schloter $(\bowtie)$

Department for Terrestrial Ecogenetics, Helmholtz Zentrum München, German Research Center for Environmental Health, Institute of Soil Ecology,

Ingolstädter Landstr. 1,

85764 Neuherberg, Germany

e-mail: schloter@helmholtz-muenchen.de

R. Matyssek

Ecophysiology of Plant, Department of Ecology and Ecosystem Management, Technische Universität München, Am Hochanger 13, 85354 Freising, Germany the 'Deutsche Forschungsgemeinschaft', DFG) has been established in the Munich area (Germany).

The mechanistic and ecological perspective of GDB makes understandable that "third-party trade-offs" between further internal (e.g. reserve storage, reproduction) or external resources (e.g. driven through symbionts or other associative soil micro-organisms), may intensely impact on and modulate the principal resource trade-off addressed by GDB between growth and defence (Stitt and Schulze 1994; Heil and Baldwin 2002; Stamp 2003; Matyssek et al. 2005).

This integrated view on GDB requires spatiotemporal process scaling that bridges gene regulation, metabolism, whole-plant functionality and resource flux at the stand level, being aware of the intense resource interchange that occurs between plants and their environment at the specific field sites. The scarcity of knowledge about the mechanistic and ecological foundations of GDB (Heil and Baldwin 2002, Stamp 2003) is evident, in particular, in forest trees, as their longevity and dimension pose a particular spatiotemporal challenge on research. Process scaling is to be extended, therefore, across plant-ontogenetic stages and a range of growth conditions, the latter being most distinctively represented by controlled, short-term chamber studies (where most of the currently available evidence is derived from, while being restricted to juvenile trees; e.g., Kolb and Matyssek 2001) versus long-term experimentation understand conditions with adult forest trees (e.g., Matyssek et al. 2007). In view of such challenges, scaling concepts that integrate 
mechanistic and ecological demands were introduced (Sandermann and Matyssek 2004) and are pursued by SFB 607.

In this focus mainly experiments are needed that bridge the scales from short-term experiments in chambers and greenhouses under controlled conditions with young trees and long-term studies in mature stands in natural forests. Furhermore, there is an urgent need for data about carbon fluxes and nutrient balances in the mycorrhizosphere (1) to understand the consequences of altered carbon allocation patterns in trees upon changes in their biotic or abiotic environment for the soil system, and (2) to follow feedback loops to plants in terms of nutrient supply. This latter task is only feasible in closed systems mainly if stable isotopes (e.g., ${ }^{13} \mathrm{C}-\mathrm{CO}_{2}$ fumigation or ${ }^{15} \mathrm{~N}$ labelled litter material) are used. The ultimate aim is the completion of resource balances between trees and microorganisms.

In such a respect lysimeters provide a useful tool. In principle, lysimeters are simply tubes made out of steel, with a height up to $2 \mathrm{~m}$ and a surface area of $1 \mathrm{~m}^{2}$, which are placed outdoor. They may be filled with soil monoliths from a field site of interest or different soil horizonts may be arranged by layers in the lysimeters according to the natural horizontation for simulating the original soil structure and density. Lysimeters have been originally designed for the approval of new pesticides in the late 1960s. Therefore, from the very beginning, lysimeters were envisaged as closed systems to eventually calculate resource fluxes and metabolic processes of the investigated chemicals. However, exactly this kind of instrumentation is needed for the questions adressed above: a closed system, which can be used under field conditions with a size that allows tree growth for up to 10 years.

In this special issue data from a joint lysimeter experiment with 6-year- old (Fagus sylvatica L.) trees are presented, including studies from plant (eco) physiology, soil microbiology, soil science and modelling. It was the aim of this experiment to clarify resource conflicts between growth and defence of plants by mainly addressing effects of competition and biotic belowground relationships, being aware that interactions between mycorrhizal fungi, competitors and parasites form a "unity" in the control of the plant's resource allocation (Matyssek et al. 2005). To assess the consequences of changed allocation for tree performance, an abiotic (ozone fumigation) and a biotic (Phytophthora citricola inoculation) stressor were used to modulate stress response.

To this end, eight lysimeters as well as the surrounding area were filled in March 1999 with natural soil from the Höglwald forest (Bavaria, Germany, $48^{\circ} 18^{\prime} \mathrm{N} 11^{\circ} 05^{\prime} \mathrm{E}$ ). In November 2002, four three-year-old beech saplings were planted into each lysimeter (for details see Schloter et al. 2005). In the surrounding area of the lysimeters additional tree saplings were planted at the same density, to obtain a homogeneous forest stand. To avoid nitrogen limitation during the experimental period, beech litter was collected from the lysimeter field, mixed with ${ }^{15} \mathrm{~N}$-labelled litter produced in the greenhouse, and subsequently added to the lysimeter area. From June 2003 onwards, the whole lysimeter area was fumigated with air $\left(8001^{*} \mathrm{~min}^{-1}\right.$, provided by four compressors) released through a curtain-like tube system. Four lysimeters were additionally fumigated with an experimentally enhanced ozone regime (free-air $\mathrm{O}_{3}$ fumigation approach, adapted from Werner and Fabian 2002). To avoid atmospheric exchange between the ozone-fumigated and the control lysimeters, Plexiglass walls of 2-m height were installed between the two $\mathrm{O}_{3}$ regimes. $\mathrm{O}_{3}$ concentration in the ozone-fumigated area were adjusted to twice ambient $\mathrm{O}_{3}$, compared with the control area, with a restriction of $150 \mathrm{nmol} \mathrm{mol}^{-1}$ to avoid acute ozone injury. Details about these technical issues of the lysimeter experiment can be found in Winkler et al. (2009a, this issue).

In spring 2006 two lysimeters of each treatment (ozone-fumigated and control lysimeters) were inoculated with P. citricola into the soil to simulate the effects of a biotic stressor on the carbon allocation pattern of the trees. Hence, four treatments in total were available for analysis (control; control+ozone; control $+P$. citricola; ozone + P. citricola). By using quantitative PCR no differences in root infection with $P$. citricola were observed between the ozone treatments (Fleischmann et al. 2009, this issue).

After leaf expansion at the beginning of June 2006, in addition to the $\mathrm{O}_{3}$ fumigation, ${ }^{13} \mathrm{C}-\mathrm{CO}_{2}$-labelling was carried out throughout the growing season until September, using ${ }^{13} \mathrm{C}$-depleted $\mathrm{CO}_{2}$ derived from fossil-fuel burning $\left(\mathrm{CO}_{2}\right.$ fossil $)$. Labelling was performed by enhancing the atmospheric $\mathrm{CO}_{2}$ concentration in both treatments by $75 \mu 1^{*} 1^{-1} \quad \mathrm{CO}_{2}$ fossil 
$\left(\delta^{13} \mathrm{C}_{\text {fossil }}=-47 \%\right.$ o $\left.\mathrm{V}-\mathrm{PDB}\right)$ using the same tubing system as for the $\mathrm{O}_{3}$ fumigation. $\mathrm{CO}_{2}$ concentrations were measured online by means of photo-acoustic $\mathrm{CO}_{2}$-controllers. This approach has been tested and optimised before in an open-top experiment. Data on the sensitivity of this method and on the dynamics of carbon flow into different plant compartments as well as into the soil can be found in Esperschütz et al. (2009a, this issue).

It is demonstrated in this special issue that the plant physiology and resource allocation were affected by the different treatments. Ozone led to a distinct reduction in overall plant biomass compared with the control treatments. However, this was not oberserved for trees that had been infected with P. citricola (Winkler et al. 2009b, this issue). Similarly, Fleischmann et al. (2009, this issue) showed that even though sucrose and starch concentrations in leaves were diminished in ozonetreated plants after four years of ozone fumigation, root infection with $P$. citricola only reduced sucrose concentrations. Olbrich et al. (2009, this issue) investigated changes in transcript patterns due to the ozone stress in 2005 and 2006. Fewer transcriptome changes were found in 2005 compared with 2006. Expression of genes involved in the cell structure, stress response, signal transduction, as well as disease and defence mechanisms could be observed in leaves from ozone stressed trees in both years. Transcripts involved in amino acid metabolism, BAT1 transporters, and O-methyl transferases (OMTs) were elevated in 2006. An early response to ozone on primary metabolism, or, more precisely, on plant growth and photosynthesis, was observed particularly in the year 2006

Also root biomass was affected by the different treatments. Biomass partitioning between fine and coarse roots as well as vertical root distribution were significantly affected by the ozone fumigation, as well as by the inoculation with $P$. citricola compared with the control, where no stressor was applied (Winkler et al. 2009b, this issue). While elevated $\mathrm{O}_{3}$ reduced standing biomass of coarse and fine roots, especially below $100 \mathrm{~cm}$ depth, $P$. citricola infection increased fine root biomass. However, the fine root proportion on total root biomass increased under elevated $\mathrm{O}_{3}$.

In addition, a phytotron study was designed to extend the factorial interactions studied in the lysimeters to inter-specific competitive systems with beech and spruce saplings (Picea abies; Luedemann et al. 2009, this issue). Contrasting with spruce, elevated $\mathrm{O}_{3}$ limited leaf and root biomass development, photosynthetic performance and $\mathrm{N}$ uptake of beech. The growth limitation by $\mathrm{O}_{3}$ was accompanied by increased resistance in beech against the pathogen. Conversely, spruce displayed enhanced susceptibility in the combined $\mathrm{O}_{3} / P$. citricola treatment.

Changes in root biomass root morphology and most likely root exudation pattern in response to the stressors induced also changes in microbial community structure and function in the mycorrhizosphere. Esperschütz et al. (2009b, this issue) demonstrated the influence of long-term chronic ozone exposure on carbon fluxes from young beech trees into microbial communities in the rhizosphere and into the dissolved organic carbon (DOC) fraction. Microbial biomass and individual microbial communities in the rhizosphere of young beech trees are mainly driven by factors related to the seaso. Only some part of the microbial community profited from the trees' recent $\mathrm{C}$ assimilation. All other microbes depended on food web initialisation. Mainly Gram-negative bacteria in the rhizosphere were favoured by elevated $\mathrm{O}_{3}$ concentrations in the atmosphere. Obviously, they were able by changes in their outer membrane structure to adapt best to the changes in the rhizosphere.

A distinct effect on microbial community function upon ozone exposure was also described by Pritsch et al. (2009, this issue), as depression of soil enzymatic activities in the mycorrhizosphere was demonstrated under ozone exposure. Surprisingly, the biotic stressor, P. citricola, had an opposite effect on the enzymatic activities, indicating that both stressors induced contrasting response in the plant soil system. However, a combination of biotic and abiotic stressors resulted in reduced enzymatic activities.

Müller et al. (2009, this issue) used NMR spectroscopy and physical fractionation to show that the changes in microbial community structure and function in the mycorrhizoshere also affected formation of soil organic matter, even after the relatively short study period in terms of soil evolution. Although most significant differences between treatments were found in different soil layers, also distinct effects in quality and quantity of the different fractions that were analysed were found in response to the four treatments of this study. 
The elaborated experimental data were used to validate a simulation model developed by Gayler et al. (2009, this issue) that deals with the effects of biotic and abiotic stress on the plant soil system with respect to GDB. The simulation results were consistent with the observed decreased growth rates and shifts in resource allocation of the trees under elevated ozone. Furthermore, the model was able to explain variation in growth of the trees between the replicate lysimeters. Such differences were related to varying hydraulic properties in the replicates, rather than to differences in the initial biomass of the trees.

The studies reported here reflect high functional plasticity of the tree-soil system in response to abiotic and biotic stressors. In particular, the belowground component represented by roots and microorganisms, forming a functional unit (mycorrhizosphere) appear to be a determinant in tree resource allocation and system resource flux, and hence, in tree and system responsiveness. In this context, the presented evidence meets a current demand in theory development on the plant's challenge in balancing growth versus stress defence (Heil and Baldwin 2002; Matyssek et al. 2005), i.e. by providing mechanistic grounds for the "growth-defence balance hypothesis" (GDB) and GDB in relation to defined and ecologically meaningful field scenarios.

\section{References}

Esperschütz J, Gattinger A, Buegger F, Lang H, Munch JC, Schloter M, Winkler JB (2009a) A continuous labelling approach to recover photosynthetically fixed carbon in plant tissue and rhizosphere organisms of young beech trees (Fagus sylvatica L.) using ${ }^{13} \mathrm{C}$ depleted $\mathrm{CO}_{2}$. Plant Soil 323:21-29, doi:10.1007/s11104-009-9998-9

Esperschütz J, Pritsch K, Gattinger A, Welzl G, Haesler F, Buegger F, Winkler JB, Munch JC, Schloter M (2009b) Influence of chronic ozone stress on carbon translocation pattern into rhizosphere microbial communities of beech trees (Fagus sylvatica L.) during a growing season. Plant Soil 323:85-95, doi:10.1007/s11104-009-0090-2

Fleischmann F, Winkler JB, Oßwald W (2009) Effects of ozone and Phytophthora citricola on non-structural carbohydrates of European beech (Fagus sylvatica) saplings. Plant Soil 323:75-84, doi:10.1007/s11104-009-9927-y

Gayler S, Klier C, Mueller CW, Weis W, Winkler JB, Priesack E (2009) Analysing the role of soil properties, initial biomass and ozone on observed plant growth variability in a lysimeter study. Plant Soil 323:125-141, doi:10.1007/ s11104-009-9993-1
Heil M, Baldwin IT (2002) Fitness costs of induced resistance: emerging experimental support for a slippery concept. Trends Plant Sci 7:61-67

Herms DA, Mattson WJ (1992) The dilemma of plants: to grow or defend. Q Rev Biol 67:283-335

Kolb TE, Matyssek R (2001) Limitations and perspectives about scaling ozone impacts in trees. Environ Pollut 115:373-393

Loomis WE (1953) Growth and differentiation-and introduction and summary. In: Loomis WE (ed) Growth and differentiation in plants. Iowa State College Press, Ames, pp 1-17

Lorio PL Jr (1988) Growth and differentiation balance relationships in pines affect their resistance to bark beetles (Coleoptera:: Scoloytidae). In: Mattson WJ, Levieux J, Bernard-Dagan C (eds) Mechanisms of woody plant defenses against insects: search for pattern. SpringerVerlag, New York, pp 73-92

Luedemann G, Matyssek R, Winkler JB, Grams TEE (2009) Contrasting ozone $\times$ pathogen interaction as mediated through competition between juvenile European beech (Fagus sylvatica) and Norway spruce (Picea abies). Plant Soil 323:47-60, doi:10.1007/s11104-009-9945-9

Matyssek R, Schnyder H, Elstner EF, Munch JC, Pretzsch H, Sandermann H (2002) Growth and parasite defence in plants: the balance between resource sequestration and retention: in lieu of a guest editorial. Plant Biol 4:133-136

Matyssek R, Agerer R, Ernst D, Munch JC, Osswald W, Pretzch H, Priesack E, Schnyder H, Treutter D (2005) The plant's capacity in regulating resource demand. Plant Biol 7:560-580

Matyssek R, Bahnweg G, Ceulemans R, Fabian P, Grill D, Hanke DE, Kraigher H, Osswald W, Rennenberg H, Sandermann H, Tausz M, Wieser G (2007) Synopsis of the CASIROZ case study: cabon sink strength of Fagus sylvatica L. in a changing environment-Experimental risk assessment of mitigation by chronic ozone impact. Plant Biol 9:163-180

Müller CW, Brüggemann N, Pritsch K, Stoelken G, Gayler S, Winkler JB, Kögel-Knabner I (2009) Initial differentiation of vertical soil organic matter distribution and composition under juvenile beech (Fagus sylvatica L.) trees. Plant Soil 323:111-123, doi:10.1007/s11104-009-9932-1

Olbrich M, Gerstner E, Welzl G, Winkler JB, Ernst D (2009) Transcript responses in leaves of ozone-treated beech saplings seasons at an outdoor free air model fumigation site over two growing seasons. Plant Soil 323:61-74, doi:10.1007/s11104-009-0129-4

Pritsch K, Esperschütz J, Haesler F, Raidl S, Winkler JB, Schloter M (2009) Structure and activities of ectomycorrhizal and microbial communities in the rhizosphere of Fagus sylvatica under ozone and pathogen stress in a lysimeter study. Plant Soil 323:97-109, doi:10.1007/ s11104-009-9972-6

Sandermann H, Matyssek R (2004) Scaling up from molecular to ecological processess. In: Sandermann H (ed) Molecular ecotoxicology of plants. Ecological Studies 170, Springer Verlag, pp 207-226

Schloter M, Winkler B, Aneja M, Koch N, Fleischmann F, Pritsch K, Heller W, Stich S, Grams E, Göttlein A, Matyssek R, Munch JC (2005) Ozone effects in the plant-rhizospherebulk soil system of young beech trees. Plant Biol 7:728-736 
Stamp N (2003) Out of the quagmire of plant defenses hypotheses. Q Rev Biol 78:23-55

Stitt M, Schulze ED (1994) Plant growth, storage, and resource allocation: from flux control in a metabolic chain to the whole-plant level. In: Schulze E-D (ed) Flux control in biological systems. Academic, San Diego, pp 57-118

Werner H, Fabian P (2002) Free-air fumigation of mature treesa novel system for controlled ozone enrichment in grownup beech and spruce canopies. Environ Sci Pollut Res 9:117-121
Winkler JB, Fleischmann F, Gayler S, Scherb H, Matyssek R, Grams TEE (2009a) Do chronic aboveground $\mathrm{O}_{3}$ exposure and belowground pathogen stress affect growth and belowground biomass partitioning of juvenile beech trees (Fagus sylvatica L.)? Plant Soil 323:31-44, doi:10.1007/ s11104-009-9968-2

Winkler JB, Lang H, Graf W, Reth S, Munch JC (2009b) Experimental setup of field lysimeters for studying effects of elevated ozone and below-ground pathogen infection on a plant-soil-system of juvenile beech (Fagus sylvatica L.). Plant Soil 323:7-19, doi:10.1007/s11104-009-9936-x 